\title{
White matter calcifications in infants: not always STORCH
}

\author{
Calcificações na substância branca em recém-nascidos: nem sempre TORCHS \\ Felipe Alba SCORTEGAGNA',2, Renato Hoffmann NUNES ${ }^{1,2}$, Luiz Celso VILANOVA ${ }^{3}$, \\ Felipe Torres PACHECO ${ }^{1,2}$, Antonio Jose da ROCHA ${ }^{1,2}$
}

A 3-month-old girl was referred for evaluation of microcephaly, seizures and spastic cerebral palsy. Prenatal care was unremarkable. Computerized tomography findings (Figure 1) showed a congenital infection pattern, however serologies and history of pregnancy complications were negative. There was a severe perinatal anoxia episode and magnetic resonance imaging findings (Figure 2) corroborated it.

Hypoxic-ischemic injury (HII) is a significant cause of mortality and neurologic disability. Imaging plays an important role in the diagnosis, providing valuable information about prognosis ${ }^{1}$.
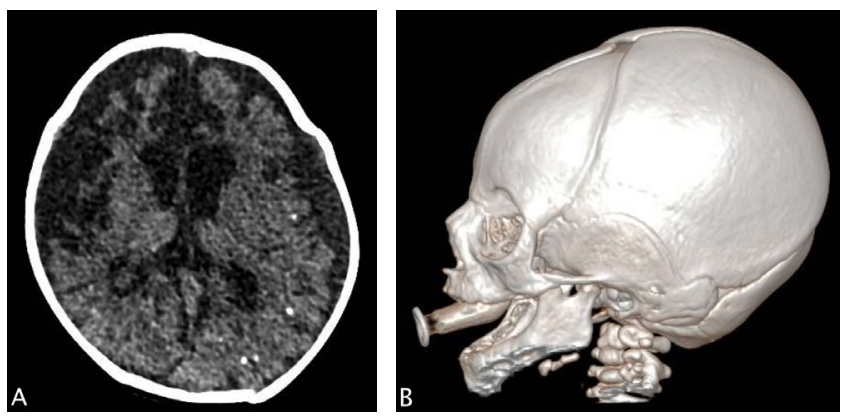

Figure 1. Unenhanced axial computerized tomography scan (A) demonstrate marked generalized atrophy with sparse dystrophic subcortical calcifications. 3D reformatted images (B) showing microcephaly and overlapping sutures, previously considered specific for congenital zika virus infection.
Cerebral calcifications are usually associated with infections, particularly STORCH (acronym for disease group comprising syphilis, toxoplasmosis, other infections, rubella, cytomegalovirus infection, and herpes simplex). Microcephaly with corticomedullary calcifications and overlapping sutures have been considered specific findings for congenital zika virus infection ${ }^{2}$. Nevertheless, HII sequela should be included in the differential diagnosis ${ }^{1}$.
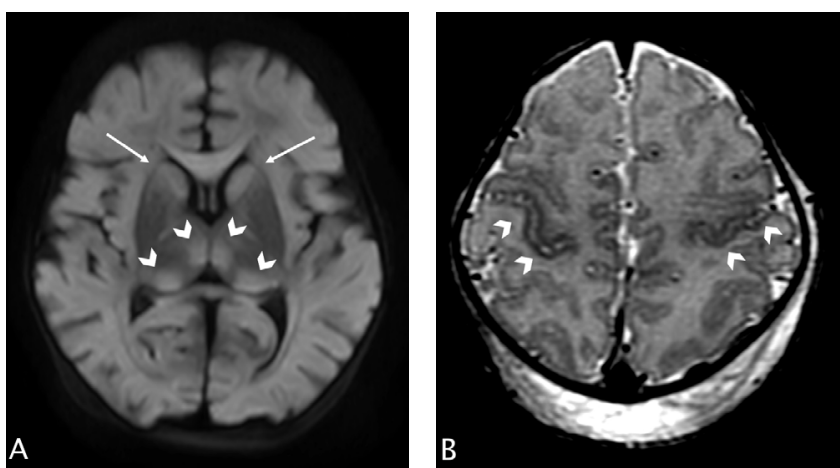

Figure 2. Axial diffusion-weighted magnetic resonance image shows hyperintensity in the anteromedial and ventrolateral thalami (arrowheads in A), and also in the basal ganglia (arrows in A). Axial T2WI shows hypointensity in the sensorimotor cortices bilaterally (arrowheads in B). These findings are highly suggestive of severe hypoxic-ischemic insult.

\section{References}

1. Chao CP, Zaleski CG, Patton AC. Neonatal hypoxic-ischemic encephalopathy: multimodality imaging findings. Radiographics. 2006 Oct;26 Suppl 1:S159-72. https://doi.org/10.1148/ rg. $26 \operatorname{si0} 65504$
2. Soares de Oliveira-Szejnfeld P, Levine D, Melo AS, Amorim MMR, Batista AGM, Chimelli L, et al. Congenital brain abnormalities and Zika virus: what the radiologist can expect to see prenatally and postnatally. Radiology. 2016 Oct;281(1):203-18. https://doi.org/10.1148/radiol.2016161584

\footnotetext{
'Santa Casa de Misericórdia de São Paulo, Divisão de Neurorradiologia, São Paulo SP, Brazil.

${ }^{2}$ Diagnósticos da América S.A., Departamento de Imagens Médicas, Divisão de Neurorradiologia, São Paulo SP, Brazil.

${ }^{3}$ Universidade Federal de São Paulo, Departamento de Neurologia e Neurocirurgia, São Paulo SP, Brazil.

Felipe Alba SCORTEGAGNA (iD) https://orcid.org/0000-0001-9088-2542; Renato Hoffmann NUNES (DD https://orcid.org/0000-0002-2483-964X; Luiz Celso VILANOVA (D) https://orcid.org/0000-0002-7631-0182; Felipe Torres PACHECO (iD https://orcid.org/0000-0002-8017-4347; Antonio Jose da ROCHA (iD https://orcid.org/0000-0003-2591-9171

Correspondence: Antonio Jose da Rocha; E-mail: a.rocha@uol.com.br.
}

Authors' contributions: FAS: imaging selection and for writing the manuscript. LCV: clinical information and diagnosis. RHN, FTP and AJR: responsible for the study concept and critical revision of the manuscript, and for interpretation of data.

Conflict of interest: There is no conflict of interest to declare.

Received on May 13, 2020; Received in its final form on May 26, 2020; Accepted on June 4, 2020 